\title{
Procesy korozyjne w rafineriach i zapobieganie ich skutkom poprzez stosowanie inhibitorów korozji
}

\begin{abstract}
Korozja instalacji podczas procesu przeróbki ropy naftowej w rafineriach jest ogromnym problemem technicznym. Skutki procesów korozyjnych wiążą się zwykle z dodatkowymi, często znacznymi kosztami, dlatego też wykorzystywane są różne metody ochrony przed korozją. Jedną z rozpowszechnionych metod jest stosowanie inhibitorów korozji. W publikacji przedstawiono opis wykorzystywanych w INiG - PIB metod badań laboratoryjnych właściwości funkcjonalnych inhibitorów korozji dla przemysłu rafineryjnego oraz opis przemysłowych metod zapobiegania korozji w rafineriach.
\end{abstract}

Słowa kluczowe: rafineria, korozja, inhibitory korozji, wheel test, aparat RCE.

\section{Corrosion processes in refineries and methods of preventing the effects of corrosion by the use of corrosion inhibitor}

\begin{abstract}
Corrosion in the plant during the processing of crude oil in refineries is a huge technical problem. Effects of the corrosion processes result in a considerable amount of additional costs, and therefore different methods of corrosion protection are used. One of the widespread methods of corrosion protection, is the use of corrosion inhibitors. This publication describes methods of laboratory testing of functional properties of corrosion inhibitors for the refinery industry and description of methods of preventing corrosion in refineries.
\end{abstract}

Key words: refinery, corrosion, corrosion inhibitors, Wheel test, RCE apparatus.

\section{Wprowadzenie}

W rafineriach podczas przetwarzania ropy naftowej może zachodzić wiele procesów korozji. Przyczyny ich występowania zależą od specyfiki procesów rafineryjnych, właściwości fizykochemicznych strumieni węglowodorowych oraz parametrów procesowych, w tym temperatury, ciśnienia i szybkości przepływu. Usuwanie skutków procesów korozji w rafineriach wiąże się zwykle z dużymi kosztami, a nawet z koniecz- nością wymiany elementów instalacji i urządzeń, dlatego też wykorzystuje się różne metody ochrony wyposażenia przed korozją. Dodatkowymi negatywnymi skutkami korozji są zagrożenia pożarowo-wybuchowe oraz skażenie środowiska.

Jedną z szeroko stosowanych metod ochrony przed korozją jest użycie inhibitorów korozji, dozowanych do strumieni węglowodorowych w sposób ciągły.

\section{Procesy korozyjne w rafineriach $[1-10,13]$}

Korozja jest to niszczenie materiałów pod wpływem chemicznej lub elektrochemicznej reakcji z otaczającym środowiskiem i/lub na skutek działania mikroorganizmów. W rafineriach procesy korozyjne dotyczą głównie instalacji wykonanych ze stali (węglowa, stopowa) oraz elementów aparatury i urządzeń z mosiądzu. Postęp korozji mierzony jest głównie poprzez ocenę jej szybkości. Szybkość korozji zależy głównie od szeregu czynników wymienionych poniżej, lecz również od przeciążenia materiałów, prędkości przepływu węglowodorów oraz temperatury i ciśnienia towarzyszących procesom rafineryjnym. Im temperatura procesu jest wyższa, tym szybkość korozji jest większa. W rafineriach 
nie stosujących inhibitorów korozji, szybkość korozji stalowych elementów instalacji może wynosić od 1 do kilku mm/rok, a w przypadku stali węglowych nawet do $10 \mathrm{~mm} /$ rok, w zależności od jakości surowca i warunków pracy. Oprócz pomiaru szybkości korozji w rafineriach oceniany jest również stopień nawodorowania stali, ilość tworzących się osadów oraz obecność wżerów i pęknięć elementów konstrukcyjnych.

Procesy korozyjne w rafineriach występują na instalacjach destylacji ropy naftowej DRW, ciągłego krakingu katalitycznego, hydroodsiarczania i reformingu benzyn, fluidalnego krakingu katalitycznego, w wytwórni olefin, w zbiornikach magazynowych i rurociągach oraz w układach wody chłodzącej. Do awarii będących skutkiem procesów korozyjnych dochodzi głównie w urządzeniach takich jak: kolumny, szczególnie w szczytowych sekcjach, kondensatory powietrzne, wymienniki, rurociągi oparowe, przegrzewacze pary, zbiorniki, pompy, zawory, kominy i reaktory $[4,6,7]$.

Eksploatowanej ropie naftowej zawsze towarzyszy woda produkcyjna. Wydobywana ropa zawiera różne ilości wody, w zależności od złoża. W jej składzie znajdują się także sole nieorganiczne, takie jak: chlorki (sodu, potasu, wapnia, magnezu), siarczany (sodu, potasu, magnezu) i węglany. Obecność wody i soli jest przyczyną korozji urządzeń procesowych podczas przerobu ropy naftowej. W roztworach zawierających sole nieorganiczne zachodzą procesy korozji elektrochemicznej, spowodowane działaniem ogniw galwanicznych tworzących się między spasywowaną powierzchnią metalu a powierzchnią, która tej warstewki nie posiada. Efektem korozji elektrochemicznej są wżery korozyjne [1].

Korozja wynikająca z oddziaływania siarkowodoru w ropie naftowej nazywana jest korozją „kwaśną”. Ropa naftowa często zawiera nawet kilka procent siarkowodoru, chociaż znane są również ropy z kilkunastoprocentowym udziałem tego związku. Siarkowodór podczas przerobu ropy naftowej uwalnia się, rozpuszcza się w wodzie, obniżając jej pH, i powoduje bardzo agresywną korozję. Przyczyną uwalniania się siarkowodoru są również reakcje rozkładu organicznych związków siarki. W wyniku reakcji siarkowodoru z żelazem powstaje siarczek żelaza FeS oraz wodór $\mathrm{H}_{2}$. Siarczek żelaza tworzy powłokę na powierzchni metalu i w pierwszej fazie hamuje „kwaśną” korozję, lecz nawet niewielkie uszkodzenie tej powłoki jest przyczyną intensyfikacji korozji. „Kwaśna" korozja powoduje powstawanie wżerów, a część wodoru wnika do stali i staje się przyczyną pęcherzenia stali i kruchości wodorowej.

$$
\mathrm{Fe}^{\mathrm{o}}+\mathrm{H}_{2} \mathrm{~S} \rightarrow \mathrm{FeS}+\mathrm{H}_{2}
$$

Duże zniszczenia korozyjne są spowodowane obecnością ditlenku węgla podczas przerobu ropy naftowej. Korozja wywołana występowaniem tego związku jest często nazywana „neutralną” lub „słodkąa” korozją. Ditlenek węgla, rozpuszczając się w wodzie, tworzy kwas węglowy $\mathrm{H}_{2} \mathrm{CO}_{3}$, który reaguje $\mathrm{z}$ żelazem, dając węglan żelaza $\mathrm{FeCO}_{3}$, powstaje również przy tym wodór. Ditlenek węgla, rozpuszczając się w wodzie, obniża jej odczyn $\mathrm{pH}$, co z kolei powoduje wzrost szybkości korozji. Charakterystyczną cechą korozji wynikającej z obecności ditlenku węgla jest obecność wygładzonych krawędzi instalacji.

$$
\begin{gathered}
\mathrm{CO}_{2}+\mathrm{H}_{2} \mathrm{O} \rightarrow \mathrm{H}_{2} \mathrm{CO}_{3} \\
\mathrm{H}_{2} \mathrm{CO}_{3}+\mathrm{Fe}^{\mathrm{o}} \rightarrow \mathrm{FeCO}_{3}+\mathrm{H}_{2}
\end{gathered}
$$

Podczas wskazanych reakcji elektrochemicznych może powstawać wodór atomowy, który przenika do wnętrza struktury krystalicznej metalu (stali, żelaza). Następnie atomy te, łącząc się, tworzą wodór cząsteczkowy, którego gromadzenie się zwiększa ciśnienie wewnętrzne materiału. Stanowi to przyczynę powstawania pęknięć sieci krystalicznej. W wyższych temperaturach $\left(>200^{\circ} \mathrm{C}\right)$ korozja wodorowa może zachodzić w fazie gazowej, czego powodem jest zachodząca reakcja dysocjacji cząsteczki $\mathrm{H}_{2}$.

Korozja przebiegająca w fazie ciekłej wywołana oddziaływaniem wodoru jest zwykle efektem działania ditlenku węgla i/lub siarkowodoru. Ponieważ zjawisko to wiąże się ze spadkiem plastyczności i pękaniem materiału konstrukcyjnego, nazywane jest również kruchością wodorową. Negatywne oddziaływanie wodoru zachodzi najszybciej, gdy odczyn pH wody produkcyjnej kształtuje się poniżej 4,0 [2].

W rafineriach duże zniszczenia korozyjne wywołane są również obecnością chlorowodoru. Chlorowodór $\mathrm{HCl}$ powstaje w wyniku hydrolizy chlorków wapnia i magnezu podczas procesu podgrzewania ropy naftowej lub rozkładu organicznych związków chloru w procesach destylacji ropy naftowej i hydroodsiarczania benzyn. Chlorowodór powoduje drastyczne obniżenie odczynu pH wody. Czynnikami korozyjnymi w rafineriach są również kwasy naftenowe zawarte $\mathrm{w}$ ropie naftowej [7].

Korozja biologiczna MIC (ang. microbiologically induced corrosion) jest procesem intensyfikowanym działaniem bakterii, a produkty przemian metabolicznych bakterii, takie jak siarkowodór, kwasy organiczne i nieorganiczne, powodują korozję i wzmagają jej szybkość. W rafineriach procesy korozyjne wywołane są głównie działaniem bakterii redukujących siarczany SRB (ang. sulfate-reducing bacteria), z gatunku beztlenowych Desulfovibrio desulfuricans, które namnażają się w warunkach anaerobowych w ropie naftowej. Bakterie te są najbardziej aktywne pod powierzchnią kamienia powstałego na skutek osadzania osadów. Bakterie SRB powodują redukcję jonów siarczanowych do siarkowodoru i/lub siarczków według reakcji [1]: 


$$
\begin{gathered}
4 \mathrm{Fe}+\mathrm{SO}_{4}{ }^{2-}+4 \mathrm{H}_{2} \mathrm{O}=3 \mathrm{Fe}(\mathrm{OH})_{2}+\mathrm{FeS}+2 \mathrm{OH}^{-} \\
\mathrm{Fe}^{2+}+\mathrm{H}_{2} \mathrm{~S}=\mathrm{FeS}+2 \mathrm{H}^{+}
\end{gathered}
$$

Procesy korozyjne w rafineriach intensyfikowane są również działaniem cyjanowodoru, obecnego $\mathrm{w}$ gazach rafineryjnych, który rozpuszcza pasywującą warstwę ochronną utworzoną na powierzchni metalu, zgodnie z równaniem:

$$
\mathrm{FeS}+2 \mathrm{HCN} \rightarrow \mathrm{Fe}^{2+}+2 \mathrm{CN}^{-}+\mathrm{H}_{2} \mathrm{~S}
$$

W wyniku rozpuszczenia warstwy ochronnej (FeS) z powierzchni stalowych wodór powstały w reakcji żelaza z siarkowodorem dyfunduje do wnętrza stalowych materiałów, co w efekcie powoduje pęcherzenie stali i kruchość wodorową.

\section{Skutki procesów korozyjnych}

Korozja równomierna (ogólna) jest najmniej niebezpiecznym wynikiem działań korozyjnych, gdyż nie wpływa bezpośrednio na zmianę wytrzymałości materiału.

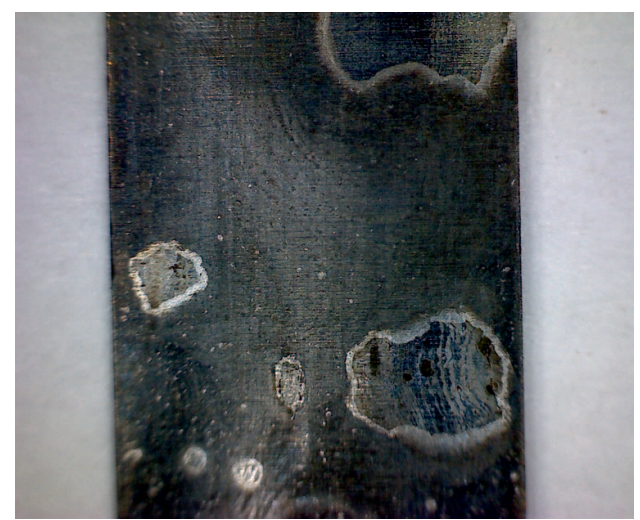

Rys. 1. Fotografia płytki metalowej - korozja równomierna

Korozja miejscowa, głównie w postaci wżerów, może być przyczyną awarii wynikającej z przerwania powłoki metalowej, np. rury w miejscu głębokiego wżeru [11, 12].

Najgroźniejsza, zwłaszcza dla stali chromowych, jest korozja międzykrystaliczna, przebiegająca na granicy ziaren metalu, powoduje bowiem silny spadek wytrzymałości materiałów konstrukcyjnych.
Do niekorzystnych skutków procesów korozyjnych w rafineriach należy również tworzenie się osadów, które zatykają wymienniki ciepła, wiązki rur, filtry, rurki, zawory i zanieczyszczają rurociągi technologiczne. Ułatwiają także zachodzenie korozji podosadowej.

Końcowymi efektami korozji podczas przetwarzania ropy naftowej są postoje instalacji, pogorszenie jakości destylatów oraz zanieczyszczenie środowiska.

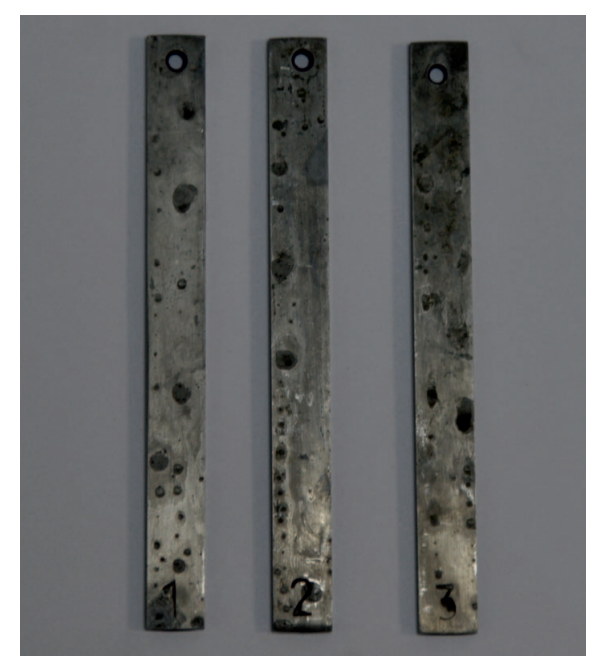

Rys. 2. Fotografia płytek metalowych - korozja wżerowa

\section{Zapobieganie korozji w rafineriach poprzez stosowanie inhibitorów korozji}

Jedną z metod zapobiegania korozji w rafineriach jest wykorzystywanie inhibitorów. W instalacjach rafineryjnych inhibitory dozuje się w sposób ciągły do strumieni węglowodorowych, w ilości od $5 \mathrm{mg} / \mathrm{kg}$ do $20 \mathrm{mg} / \mathrm{kg}$. Przyjmuje się, że właściwa ochrona przeciwkorozyjna powinna zapewnić spadek szybkości korozji stali węglowej do poziomu poniżej $0,11 \div 0,25 \mathrm{~mm} / \mathrm{rok}$, poziomu nawodorowania stali węglowej do wartości poniżej $0,2 \mathrm{ppm} \mathrm{H}_{2} / \mathrm{m}$-c, a ilości osadów do poziomu poniżej $2,0 \mathrm{~g} / \mathrm{m}^{2}$ na dobę.

W instalacjach destylacji rurowo-wieżowej DRW, gdzie surowcem jest ropa naftowa, do głównych czynników korozyjnych należą kwaśne gazy: $\mathrm{H}_{2} \mathrm{~S}_{\text {i CO}}$, kwasy nieorganiczne: $\mathrm{HCl}, \mathrm{H}_{2} \mathrm{SO}_{3}, \mathrm{H}_{2} \mathrm{SO}_{4}, \mathrm{H}_{2} \mathrm{CO}_{3}$ oraz organiczne kwasy naftenowe. Czynnikiem wzmagającym korozję jest wysoka tempe- ratura procesu. Węglowodory zawierające parę wodną, chlorowodór i siarkowodór, opuszczając kolumnę destylacyjną w temperaturze około $130^{\circ} \mathrm{C}$, stają się najbardziej agresywne. Tam właśnie zachodzą najintensywniejsze procesy korozyjne. W instalacjach DRW przeciwdziała się korozji, dozując, oprócz inhibitora korozji, środki deemulgujące oraz neutralizatory kwaśnych oparów (tablica 1) [1, 4, 5, 7, 13].

Surowcem w instalacjach hydrokrakingu są frakcje próżniowe $\mathrm{z}$ DRW, procesy zachodzą w obecności katalizatora i wodoru w temperaturze $340 \div 430^{\circ} \mathrm{C}$ pod ciśnieniem wodoru $6 \div 15 \mathrm{MPa}$. Głównymi czynnikami korozyjnymi są kwaśne gazy: $\mathrm{H}_{2} \mathrm{~S}$ i $\mathrm{CO}_{2}$, amoniak, cyjanki oraz chlorki. Dozowanie ciągłe specjalnie dobranych inhibitorów korozji zapobiega procesom korozyjnym. 
Tablica 1. Metody zapobiegania korozji na instalacjach DRW [1, 4, 5, 7, 13]

\begin{tabular}{|c|c|c|c|c|}
\hline Środek chemiczny & Rodzaj procesu & Działanie & Miejsce dozowania & Kontrola procesu \\
\hline Deemulgator & $\begin{array}{c}\text { odwadnianie i odsa- } \\
\text { lanie ropy naftowej }\end{array}$ & $\begin{array}{c}\text { usuwanie chlorków } \mathrm{Ca} \\
\mathrm{i} \mathrm{Mg} \mathrm{z} \mathrm{ropy} \mathrm{naftowej}\end{array}$ & $\begin{array}{c}\text { do strumienia surowej ropy } \\
\text { w elektrodehydratorach }\end{array}$ & $\begin{array}{c}\text { ocena zawartości chlorków po } \\
\text { procesie deemulgowania }\end{array}$ \\
\hline $\begin{array}{c}\text { Wodny roztwór } \\
\text { wodorotlenku }\end{array}$ & neutralizacja & $\begin{array}{c}\text { neutralizacja } \mathrm{HCl}, \mathrm{H}_{2} \mathrm{~S}, \\
\mathrm{CO}_{2} \mathrm{i} \text { innych kwasów }\end{array}$ & $\begin{array}{c}\text { do strumienia odsolonej } \\
\text { ropy }\end{array}$ & $\begin{array}{c}\text { ocena odczynu } \mathrm{pH} \\
\text { kondensatów }\end{array}$ \\
\hline Aminy lotne & neutralizacja & $\begin{array}{c}\text { neutralizacja pozostałości } \\
\mathrm{HCl}, \mathrm{H}_{2} \mathrm{~S}, \mathrm{CO}_{2} \mathrm{i} \text { innych } \\
\text { kwasów }\end{array}$ & $\begin{array}{c}\text { do strumienia oparów } \\
\text { szczytowych kolumny }\end{array}$ & $\begin{array}{c}\text { kondensatów } \\
\text { kn odczynu }\end{array}$ \\
\hline $\begin{array}{c}\text { Inhibitory korozji } \\
\text { stali i mosiądzu }\end{array}$ & $\begin{array}{c}\text { działanie przeciwko- } \\
\text { rozyjne }\end{array}$ & $\begin{array}{c}\text { tworzą warstwę ochronną } \\
\text { na powierzchniach metali }\end{array}$ & $\begin{array}{c}\text { do strumienia orosienia } \\
\text { i oparów szczytowych } \\
\text { kolumny }\end{array}$ & $\begin{array}{c}\text { ocena szybkości korozji stali } \\
\text { i mosiądzu; ocena nawodoro- } \\
\text { wania stali oraz ilości osadów }\end{array}$ \\
\hline
\end{tabular}

Surowcem $\mathrm{w}$ instalacjach fluidalnego krakingu katalitycznego (FCC) są destylaty próżniowe $\mathrm{z}$ dodatkiem destylatów próżniowych z procesów koksowania, visbreakingu, deasfaltyzacji i destylacji atmosferycznej, których przeróbka prowadzona jest w sposób ciągły, w obecności katalizatora, w temperaturze $500 \div 550^{\circ} \mathrm{C}$ i pod ciśnieniem $0,1 \div 0,3 \mathrm{MPa}$. W procesie krakingu katalitycznego następuje rozpad obecnych w surowcu związków siarki i azotu. Głównymi czynnikami korozyjnymi są kwaśne gazy:
$\mathrm{H}_{2} \mathrm{~S}$ i $\mathrm{CO}_{2}$, amoniak, cyjanki, chlorki i kwasy organiczne. W procesie hydroodsiarczania benzyn następuje rozkład związków siarki, azotu i tlenu do siarkowodoru i amoniaku oraz rozkład chlorków $\mathrm{MgCl}_{2}$ i $\mathrm{CaCl}_{2}$ do chlorowodoru. Skutki procesów korozyjnych wywołanych ich działaniem są minimalizowane poprzez dozowanie w sposób ciągły specjalistycznych inhibitorów korozji, przystosowanych do pracy w ekstremalnych warunkach temperaturowych $[1,4,5,7,13]$.

\section{Inhibitory korozji do strumieni węglowodorowych - przegląd literatury}

W patencie PL 61535 opisano inhibitor korozji przeznaczony do ochrony instalacji DRW, zawierający produkt kondensacji kwasów tłuszczowych $\mathrm{C}_{10-20}$ z N-(2-hydroksyetylo)etylenodiaminą. W składzie inhibitora korozji ujawnionego w patencie PL 175452 znajduje się produkt kondesacji kwasu thuszczowego z DETA, zmodyfikowany urotropiną, z dodatkiem oksyetylenowanych amin i oksyetylenowanych alkoholi tłuszczowych. Przedstawiony w patencie EP 1333108 inhibitor zawiera 1,2-podstawioną imidazolinę, estry fosforowe i etoksylenowane rozgałęzione poliole. Z kolei w składzie inhibitora opisanego w patencie US 5961885 występują rozpuszczalne w pentanie: imidazolina, amid, dyspergator, związki pirydynowe. W patencie US 7682526 przedstawiono inhibitor zawierający pochodną imidazoliny zneutralizowaną dimerami/trimerami kwasów tłuszczowych, niejonowy alkilofenol, fosforany oraz pochodne kwasu dodecylobursztynowego. W zgłoszeniu US 2011/0031165 głównym składnikiem inhibitora jest innowacyjna zmodyfikowana imidazolina. Ważnym elementem ochrony przeciwkorozyjnej instalacji rafineryjnych są również inhibitory korozji miedzi, głównie z grupy związków triazolowych, których zadaniem jest ochrona konstrukcyjnych elementów z mosiądzu.

$Z$ badań stanu techniki wynika, że oferowane inhibitory, mimo deklaracji producenta o niskim dozowaniu, są często mało wydajne. Powoduje to znaczny wzrost kosztów związanych z ochroną przeciwkorozyjną. Inne ich niedoskonałości to skłonność do emulgowania, niedostateczne przeciwdziałanie osadom oraz tendencja do pienienia, co w konsekwencji powoduje zakłócanie przebiegu procesów rafineryjnych [14-19].

\section{Metody badań laboratoryjnych właściwości funkcjonalnych inhibitorów korozji dla przemysłu rafineryjnego}

Do oceny funkcjonalnych właściwości inhibitorów korozji do strumieni węglowodorowych w przemyśle rafineryjnym wytypowano kilka znormalizowanych metod badań. Metody te służą do oceny ich właściwości przeciwkorozyjnych oraz do badań ich wpływu na przebieg procesów rafi- neryjnych. Doboru metod dokonano, kierując się zaleceniami normy ASTM G 170-06 oraz własnymi doświadczeniami z badań nad korozją.

W dalszej części artykułu opisano sposób wykonania badań według metod wymienionych w tablicy 2 . 
Tablica 2. Właściwości funkcjonalne inhibitorów korozji do strumieni węglowodorowych w przemyśle rafineryjnym metody badań laboratoryjnych

\begin{tabular}{|l|c|}
\hline \multicolumn{1}{|c|}{ Nazwa badania } & Norma/metoda \\
\hline Wheel Test Method Used for Evaluation of Film-Persistent Corrosion Inhibitors for Oilfield Applications & NACE 1D182 (2005) \\
\hline $\begin{array}{l}\text { Standard Practice for Evaluating and Qualifying Oil Field and Refinery Corrosion Inhibitors using the } \\
\text { Rotating Cylinder Electrode }\end{array}$ & ASTM G185-06 \\
\hline Badanie laboratoryjne w cieczach i roztworach o temperaturze otoczenia & PN-H-04601 \\
\hline Korozja metali. Badanie laboratoryjne w cieczach i roztworach w temperaturze podwyższonej & PN-H-04602 \\
\hline Ocena szybkości korozji i stopnia nawodorowania stali & PN-H-04610 \\
\hline Standard Practice for Preparing, Cleaning, and Evaluating Corrosion Test Specimens & ASTM G1-03 \\
\hline Standard Guide for Corrosion Tests in High Temperature or High Pressure Environment & ASTM G111-97 \\
\hline Rozpuszczalność inhibitorów korozji w nośnikach & ASTM G170-06 \\
\hline Badanie skłonności do tworzenia się emulsji & ASTM G170-06 \\
\hline Badanie skłonności do pienienia & ASTM G170-06 \\
\hline
\end{tabular}

\section{Wheel test}

Wheel Test Method Used for Evaluation of FilmPersistent Corrosion Inhibitors for Oilfield Applications według NACE 1D182 (2005).

Badanie właściwości przeciwkorozyjnych inhibitorów korozji metodą wheel test jest konwencjonalną metodą badania ubytku masy, stosowaną do oceny wydajności inhibitora korozji poprzez symulację ciągłego przepływu medium korozyjnego.

Wodę korozyjną poddano barbotażowi azotem, a następnie ditlenkiem węgla, do momentu uzyskania odczynu $\mathrm{pH}$ w granicach $4,4 \div 4,8$. W przypadku badania w obecności $\mathrm{CO}_{2}$ i $\mathrm{H}_{2} \mathrm{~S}$ do wody korozyjnej dodatkowo wprowadzano siarczek sodu $\mathrm{Na}_{2} \mathrm{~S} \times 9 \mathrm{H}_{2} \mathrm{O}$ oraz lodowaty kwas octowy. Do butelek testowych zawierających wodę korozyjną i wzorcowy olej parafinowy wprowadzano badany inhibitor korozji w ilości $5 \div 20 \mathrm{mg} / \mathrm{kg}$, a następnie umieszczano w nich płytki metalowe shim stock. Do butelek testowych ponownie dozowano $\mathrm{CO}_{2}$ i szczelnie je zamykano. Butelki umieszczano w termostacie w temperaturze $65,5^{\circ} \mathrm{C}$, w aparacie obrotowym, który obracał się z prędkością 15 obr./min. Test prowadzono przez 72 godziny. Po badaniu płytki metalu oczyszczano i oceniano ubytek masy oraz ewentualną obecność korozji wżerowej. Procent ochrony przed korozją obliczano z ubytku masy próbki metalu w obecności inhibitora $\mathrm{W}$ (inhib) oraz bez jego udziału W(0).

$$
\text { Procent ochrony, \% } \mathrm{P}=\mathrm{W}(0)-\mathrm{W}(\text { inhib }) / \mathrm{W}(0) \cdot 100 \%
$$

Rysunek 3 przedstawia stanowisko do badań korozyjnych według NACE 1D182 (2005), w tym aparat obrotowy oraz zestaw butelek testowych po badaniu korozyjnym. Rysunek 4 prezentuje wygląd płytek metalowych po badaniu korozyjnym.
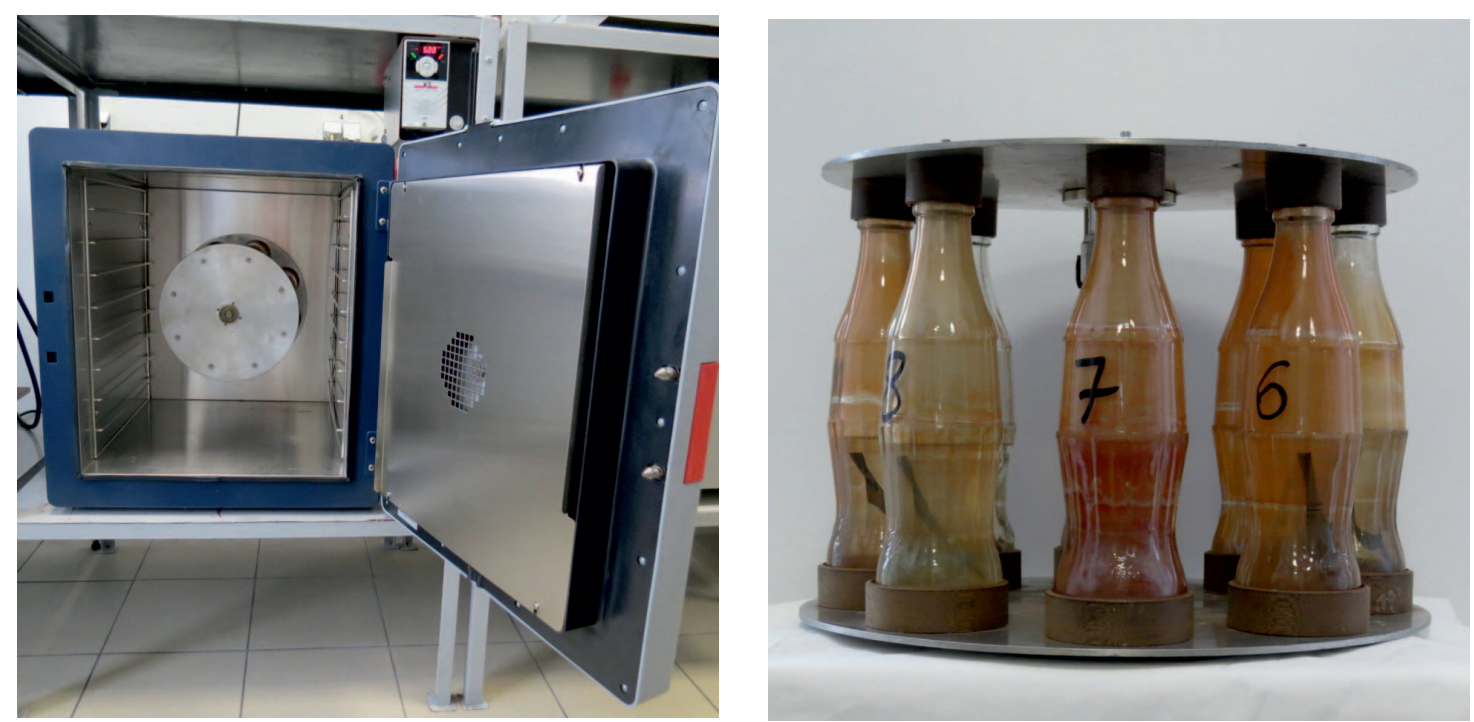

Rys. 3. Stanowisko do badań korozyjnych wheel test według NACE 1D182 (2005) - fotografia aparatu obrotowego oraz zestawu butelek testowych po badaniu korozyjnym 


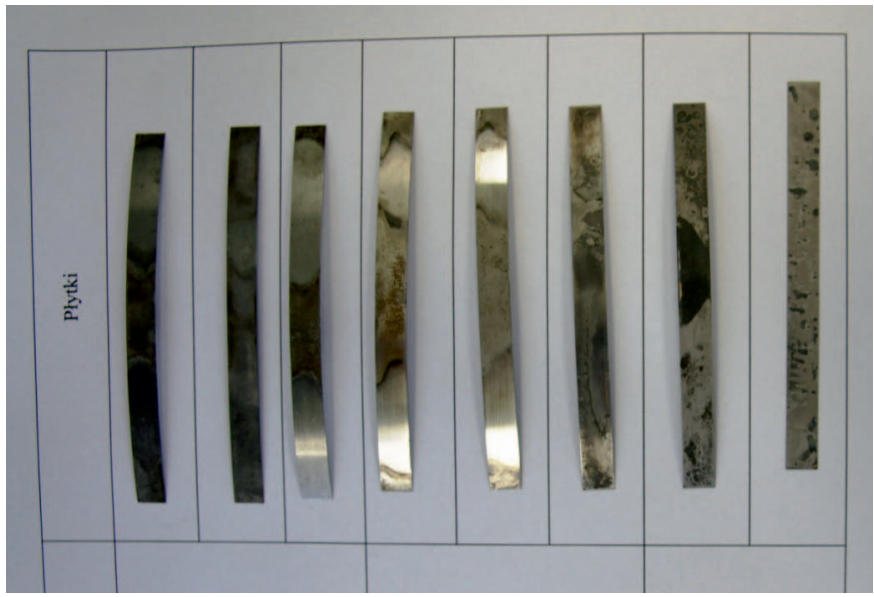

Rys. 4. Fotografia płytek metalowych po badaniu korozyjnym wheel test

\section{Aparat z cylindryczną elektrodą obrotową RCE}

Standard Practice for Evaluating and Qualifying Oil Field and Refinery Corrosion Inhibitors Using the Rotating Cylinder Electrode - według ASTM G185-06 (2012).

Aparat RCE składa się z wirującej elektrody cylindrycznej w układzie trójelektrodowym, rotatora wprawiającego ją w ruch, systemu sterowania i zabudowanego układu. Technika wirującej elektrody cylindrycznej RCE pozwala na laboratoryjną symulację rzeczywistych warunków hydrodynamicznych panujących podczas przerobu ropy naftowej. Układ badania RCE działa w szerokim zakresie liczb Reynoldsa.

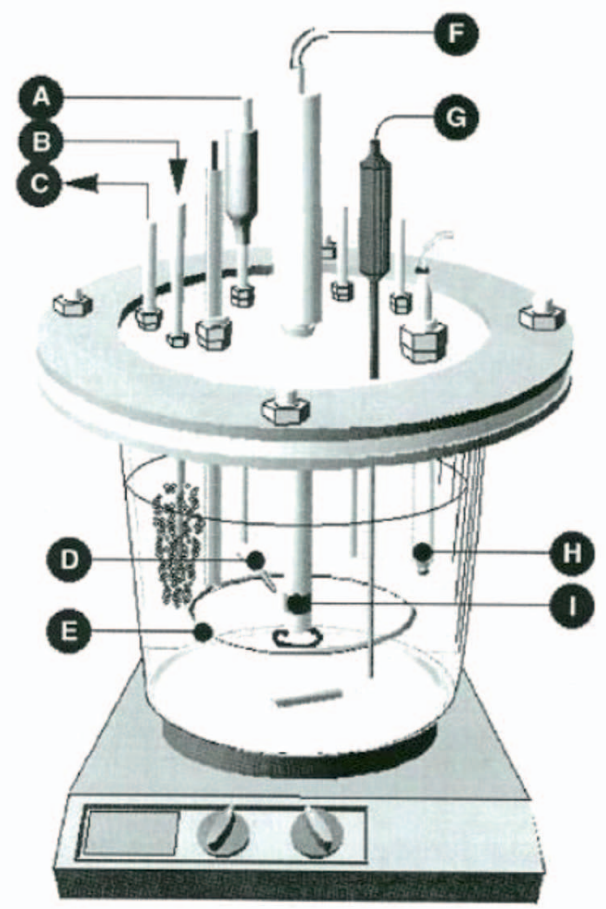

Rys. 5. Schemat układu RCE według ASTM G170-06 (2012);

A - elektroda referencyjna, B - wlot, C - wylot,

D - kapilara, E - przeciwelektroda, F - walec wirujący,

$\mathrm{G}$ - sonda temperaturowa, $\mathrm{H}$ - elektroda $\mathrm{pH}, \mathrm{I}$ - wirująca elektroda walcowa
Szybkość korozji szacowano przy użyciu klasycznych metod pomiaru utraty masy i metod elektrochemicznych. Przy zastosowaniu techniki RCE określano wpływ ciśnienia, temperatury, gazów oddziałujących korozyjnie $\left(\mathrm{SO}_{2} 1 \mathrm{lub} \mathrm{CO}_{2}\right)$, szybkości przepływu, składu ropy naftowej i solanki na właściwości inhibitujące inhibitorów rafineryjnych w stosunku do powierzchni metali.

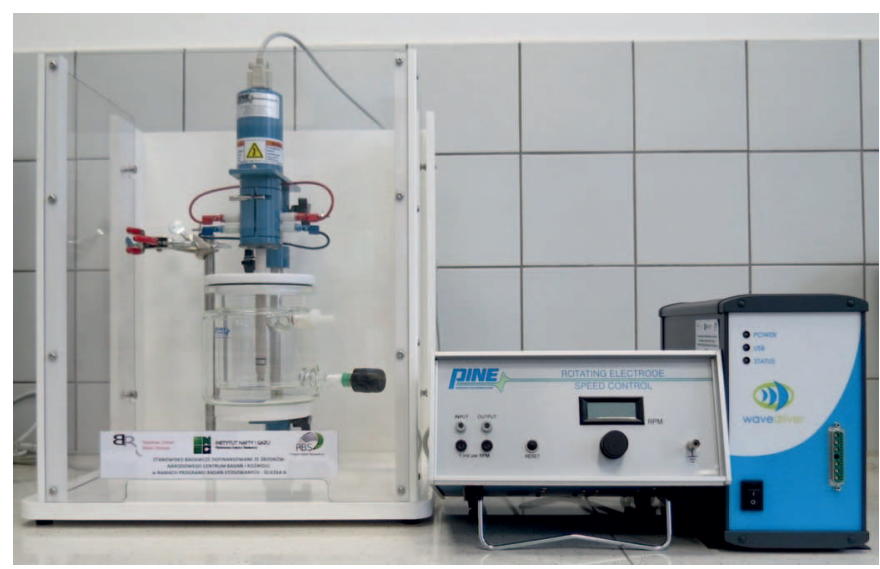

Rys. 6. Fotografia stanowiska do badań korozyjnych (aparatura została zakupiona dla INiG - PIB w ramach projektu dofinansowanego ze środków NCBiR w ramach Programu Badań Stosowanych - Ścieżka A)

\section{Statyczne badanie korozyjne}

Badanie laboratoryjne w cieczach i roztworach o temperaturze otoczenia - według PN-H-04601:1976 oraz Badanie laboratoryjne w cieczach i roztworach w temperaturze podwyższonej - według $\mathrm{PN}-\mathrm{H}$ 04602:1976.

Metoda badania korozji polega na określeniu zmian masy próbek metalu zanurzonych w medium korozyjnym z udziałem badanych inhibitorów w ściśle określonej temperaturze (rysunek 7). Szybkość korozji obliczano sposobem opisanym w badaniu wheel test. Przeprowadzano również ocenę zniszczeń korozyjnych próbek metalu po badaniu.

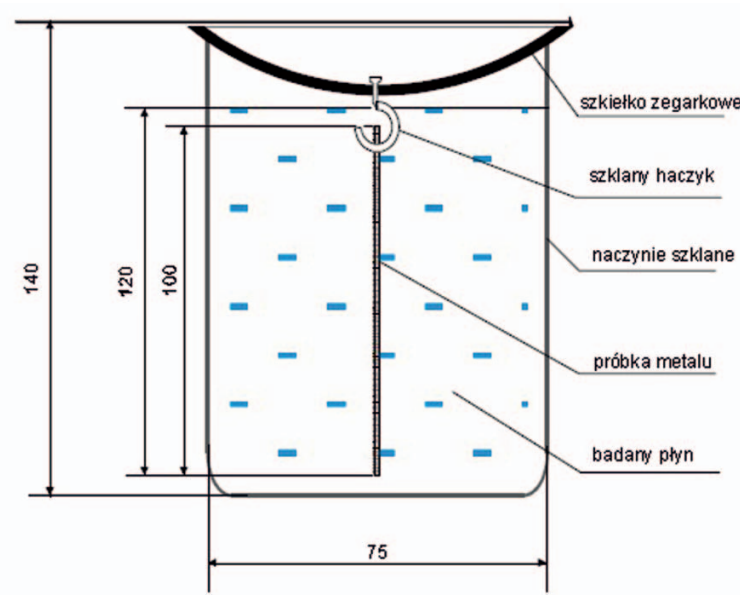

Rys. 7. Statyczne badania korozyjne - zestaw do badań 


\section{Testy ciśnieniowe w aparacie wirujący dysk RDA-100 firmy CoreLab}

Standard Practice for Preparing, Cleaning and

Evaluating Corrosion Test Specimens - według ASTM

G1-03 (2011); Standard Guide for Corrosion Tests

in High Temperature or High Pressure Environment, or Both - według ASTM G111-97 (2013); Laboratory Corrosion Testing of Metals - według NACE Standard TM0169-2000 Item No. 21200; Standard Practice for Laboratory Immersion Corrosion Testing of Metals według ASTM G31-72 (2004).

Do przeprowadzenia testów korozyjnych stosowano aparat $\mathrm{z}$ wirującym dyskiem RDA-100, który pozwala na pomiary pod ciśnieniem i w temperaturze w zakresie od $-40^{\circ} \mathrm{C}$ do $+121^{\circ} \mathrm{C}$. Urządzenie to sterowane jest komputerowo za pomocą programu RDA, który umożliwia ustawienie warunków przebiegu testu, jego automatyczne wykonanie i zapis. Badanie właściwości przeciwkorozyjnych inhibitorów korozji prowadzono w środowisku ropy naftowej i wody zawierającej sole nieorganiczne. Szybkość korozji obliczano na podstawie ubytków masy próbek metalu. Wykonywano także obserwacje wizualne próbek metalu po teście. Zastosowane w testach ciśnieniowych stężenie wszystkich badanych inhibitorów korozji było na tym samym poziomie. Jest to metoda porównawcza; punkt odniesienia stanowi próbka ropy naftowej z solanką bez udziału inhibitora korozji [11, 12].

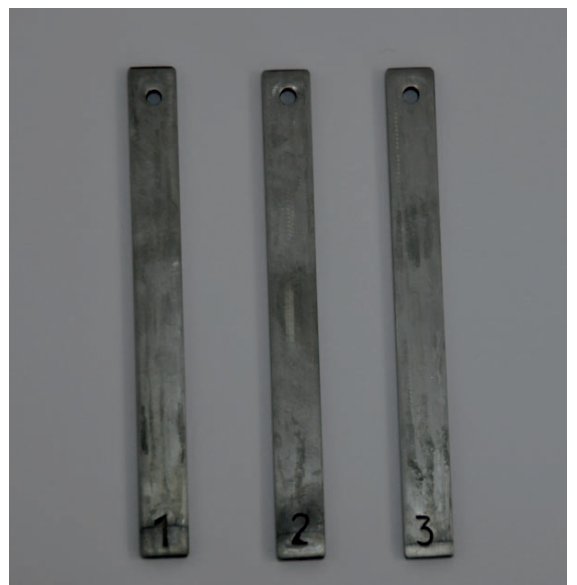

Rys. 8. Fotografia próbek ze stali po badaniu korozyjnym (fot. A. Stachowicz)

\section{Rozpuszczalność w zalecanym nośniku (wodnym lub węglowodorowym)}

Standard Guide for Evaluating and Qualifying Oilfield and Refinery Corrosion Inhibitors in the Laboratory według ASTM G170-06 (2012).

Konieczność badania rozpuszczalności w zalecanym nośniku wynika z faktu, że inhibitory korozji przed zadozowaniem do układów rafineryjnych są wstępnie rozcieńczane, tak aby ich lepkość była na odpowiednim poziomie. Rozpuszczalność inhibitorów korozji w zalecanym nośniku oceniano, biorąc pod uwagę perspektywiczną temperaturę przechowywania, często osiągającą $-20^{\circ} \mathrm{C}$. Głównymi problemami podczas przechowywania są: utrata rozpuszczalności składników aktywnych z tworzeniem się frakcji stałych lub półstałych i rozdzielanie się faz na skutek zmian rozpuszczalności. Powyższe badania odbywały się $\mathrm{w}$ temperaturze $+20^{\circ} \mathrm{C} \mathrm{i}-20^{\circ} \mathrm{C}$. Badania prowadzono dla mieszanek inhibitor korozji-węglowodory, zmieszanych w stosunku 50/50\% $(V / V)$. W cylindrze o pojemności $100 \mathrm{ml}$ sporządzono roztwory badanego inhibitora korozji w benzynie lekkiej i benzynie ciężkiej. Roztwory przechowywano w temperaturze $+20^{\circ} \mathrm{C} \mathrm{i}-20^{\circ} \mathrm{C}$ przez dwa tygodnie. Rejestrowano pojawienie się zmętnienia lub inną zmianę w cieczy, oceniano tworzenie się osadów i rozdział faz.

\section{Skłonność do tworzenia emulsji}

Standard Guide for Evaluating and Qualifying Oilfield and Refinery Corrosion Inhibitors in the Laboratory według ASTM G170-06 (2012).

Skłonność do emulgowania jest właściwością inhibitora, która powoduje, że woda i mieszanina węglowodorów tworzą emulsję. Powstała emulsja może być stabilna, co prowadzi do trudności w instalacjach produkcyjnych. Badania przeprowadzano dla mieszaniny faz węglowodorowej i wodnej. Obydwie fazy mieszano w stosunku 95:5, 75:25 oraz 50:50\% $(V / V)$, a następnie dozowano badany inhibitor korozji. Każdą próbkę mieszano intensywnie, po czym odstawiano. Obserwowano przejrzystość i kolor warstw węglowodorowej i wodnej oraz wygląd granicy międzyfazowej po $5,15,30$ i 60 minutach.

Następnie dokonywano porównania z próbą ślepą. Oceniono również czas potrzebny na pełne oddzielenie się obu faz.

\section{Oddziaływanie inhibitora korozji do strumieni węglowodorowych na ludzi i środowisko}

\section{Standard Guide for Evaluating and Qualifying Oilfield} and Refinery Corrosion Inhibitors in the Laboratory według ASTM G170-06 (2012).

Właściwością o rosnącej istotności jest oddziaływanie inhibitorów korozji na ludzi i środowisko naturalne. Problemy środowiskowe na całym świecie narastają i prawdopodobnie będą wpływać na wybór inhibitorów korozji w przyszłości. Wymagania z zakresu ochrony środowiska są nadal opracowywane, ale niektóre elementy zostały już ustalone. Zaleca się, aby biodegradacja inhibitora korozji wynosiła co najmniej 60\%, a składniki inhibitorów były nietoksyczne. 


\section{Podsumowanie}

Skutki procesów korozyjnych w rafineriach są często bardzo kosztowne, z uwagi na konieczność wymiany elementów instalacji i urządzeń. Jedną z metod ochrony przed korozją w rafineriach jest stosowanie inhibitorów korozji. W artykule zarysowano zagrożenia korozyjne występujące w rafineriach i wskazano najczęściej wykorzystywane przemysłowe metody zapobiegania procesom korozyjnym, w tym polegające głównie na dozowaniu inhibitorów korozji w sposób ciągły do strumieni węglowodorowych.

Wymagania stawiane inhibitorom korozji dozowanym do strumieni węglowodorowych są wysokie; z technicznego punktu widzenia wymaga się, aby były skuteczne, ekonomiczne i wielofunkcyjne. Inhibitory korozji muszą wykazywać bardzo dobre właściwości przeciwkorozyjne już przy niskim dozowaniu w trudnych warunkach rafineryjnych.
Powinny być kompatybilne ze strumieniami procesowymi, tak aby nie utrudniały przebiegu procesów rafineryjnych. Dodatkowo wymaga się, aby były nietoksyczne i biodegradowalne.

Szerzej omówiono metody stosowane w INiG - PIB w celu oceny właściwości przeciwkorozyjnych inhibitorów korozji do strumieni węglowodorowych w przemyśle rafineryjnym, w tym: dynamiczne badanie wheel test, dynamiczne badanie z zastosowaniem aparatu RCE, statyczne badanie korozyjne w cieczach i roztworach oraz testy ciśnieniowe w aparacie wirujący dysk RDA-100. Przedstawiono również metody służące do oceny potencjalnego wpływu badanych inhibitorów korozji na przebieg procesów rafineryjnych, do których zaliczono badanie rozpuszczalności inhibitorów korozji w nośnikach (woda/węglowodory), skłonność do tworzenia emulsji i skłonność do pienienia.

Prosimy cytować jako: Nafta-Gaz 2016, nr 3, s. 198-206, DOI: 10.18668/NG.2016.03.08

Artykuł nadesłano do Redakcji 18.02.2015 r. Zatwierdzono do druku 22.02.2016 r.

Artykuł powstał na podstawie pracy statutowej pt. Badania nad opracowaniem nowych inhibitorów korozji do strumieni węglowodorowych w przemyśle rafineryjnym - praca INiG - PIB na zlecenie MNiSW; nr zlecenia: 0068/TO/14, nr archiwalny: DK-4100-68/14 oraz projektu realizowanego zgodnie z umową $\mathrm{nr}$ PBS/3/A1/15/2015 pt. Innowacyjne środki chemiczne z udziatem zmodyfikowanej imidazoliny dla przemystu rafineryjnego, wydobywczego ropy naftowej, hutniczego i maszynowego - projekt dofinansowany ze środków NCBiR w ramach Programu Badań Stosowanych - Ścieżka A.

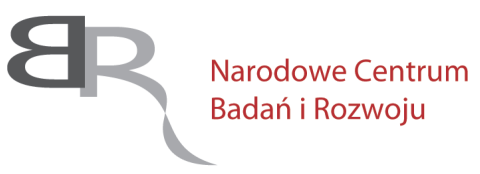
Badań i Rozwoju

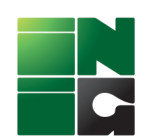

INSTYTUT NAFTY I GAZU

- Państwowy Instytut Badawczy

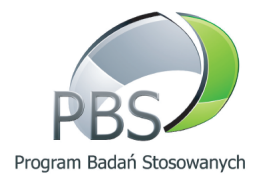

[W:] Surygała J. (red.): Ropa naftowa: właściwości, przetwarzanie, produkty. Vademecum rafinera. Warszawa, WNT, 2006, s. 540-560.

[8] Reiss Ł.: Zastosowanie testerów do wykrywania procesów korozyjnych. Konferencja Naukowo-Techniczna, AGH, 1997.

[9] Reiss Ł., Toporowski R.: Korozyjne niszczenie metali w górnictwie naftowym wywolane siarkowodorem. Konferencja Naukowo-Techniczna, AGH, Kraków 2-3.07.1998.

[10] Reiss Ł., Urba R., Toporowski R.: Badania skuteczności inhibitorów korozji w roztworach solnych. Konferencja Naukowo-Techniczna GEOPETROL, Zakopane 2000.

[11] Stachowicz A.: Korozja rur w odwiertach oraz dobór ochrony inhibitowanej w ptynach nadpakerowych. Nafta-Gaz 2013, nr 7, s. 525-531.

[12] Stachowicz A.: Korozja rur wydobywczych odwiertów gazowych z zawartościa $\mathrm{CO}_{2}$. Nafta-Gaz 2011, nr 6, s. 395-400.

[13] Tishkevich L. F., Vartapetov M. A., Kamlyk A. S., Filippov N. G., Frolov K. I., Miklyasheva I. V.: Tests of Dodigen 481 Inhibitor in Corrosive Media at the Perm'Petroleum Refinery. Chemistry and Technology of Fuels and Oils 1996, vol. 32 , no. 1 , s. $26-27$. 


\section{Patenty}

[14] Patent EP 1333108 Corrosion inhibitor for the petroleum industry, 2006.

[15] Patent PL 175452 Sposób otrzymywania imidazolinowego inhibitora korozji dla potrzeb przemystu rafineryjnego.

[16] Patent PL 61535 Sposób ochrony stali przed korozja, zwtaszcza w środowiskach kwasowych oraz w instalacjach destylacji rurowo-wieżowej $w$ rafinerii nafty.

[17] Patent US 5723061 Antifreeze composition comprising a watersoluble alcohol and a corrosion inhibitor system comprising dicarboxylic acids or salts thereof, diazole and a triazole.

[18] Patent US 5961885 Solution and method for inhibiting corrosion, 1999.

[19] Zgłoszenie patentowe US 2011/0031165 Processes for removing hydrogen sulfide from refined hydrocarbon streams, 2011.

\section{Akty normatywne}

[20] Norma ASTM G170-06 Standard Guide for Evaluating and Qualifying Oilfield and Refinery Corrosion Inhibitors in the Laboratory, 2012.

[21] Norma ASTM G185-06 Standard Practice for Evaluating and Qualifying Oil Field and Refinery Corrosion Inhibitors Using the Rotating Cylinder Electrode, 2012.

[22] Norma ASTM G1-03 Standard Practice for Preparing, Cleaning, and Evaluating Corrosion Test Specimens, 2011.
[23] Norma ASTM G111-97 Standard Guide for Corrosion Tests in High Temperature or High Pressure Environment, 2013.

[24] Norma ASTM G170-06 Standard Guide for Evaluating and Qualifying Oilfield and Refinery Corrosion Inhibitors in the Laboratory, w tym: Rozpuszczalność inhibitorów korozji w nośnikach; Badanie skłonności do tworzenia się emulsji; Badanie skłonności do pienienia, 2012.

[25] Norma NACE 1D182 Wheel Test Method Used for Evaluation of Film-Persistent Corrosion Inhibitors for Oilfield Applications, 2005.

[26] Norma PN-H-04601 Badanie laboratoryjne w cieczach i roztworach o temperaturze otoczenia, 1976.

[27] Norma PN-H-04602 Badanie laboratoryjne w cieczach i roztworach $w$ temperaturze podwyższonej, 1976.

[28] Norma PN-H-04610 Ocena szybkości korozji i stopnia nawodorowania stali, 1978.

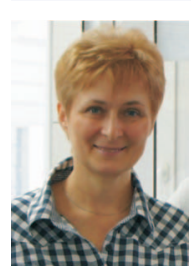

Mgr inż. Barbara GAŹDZIK

Starszy specjalista badawczo-techniczny w Zakładzie Olejów i Srodków Smarowych i Asfaltów. Instytut Nafty i Gazu - Państwowy Instytut Badawczy ul. Lubicz 25 A

31-503 Kraków

E-mail: barbara.gazdzik@inig.pl

\section{OFERTA}

\section{ZAKŁAD OLEJÓW, ŚRODKÓW SMAROWYCH I ASFALTÓW}

Zakres działania:

- opracowanie i modyfikacja technologii wytwarzania:

" olejów podstawowych (bazowych),

" środków smarowych: olejów przemysłowych i smarów plastycznych,

» wosków naftowych (parafin i mikrowosków), wosków i kompozycji specjalnych oraz emulsji woskowych,

» dodatków stosowanych podczas wydobycia i transportu ropy naftowej oraz gazu ziemnego: inhibitorów korozji, inhibitorów parafin, inhibitorów hydratów, inhibitorów hydratów i korozji, deemulgatorów oraz inhibitorów oporów przepływu ropy naftowej,

" asfaltów drogowych i przemysłowych,

» olejów technologicznych do obróbki metali: emulgujących i nieemulgujących,

» niskokrzepnących płynów do chłodnic samochodowych i spryskiwaczy samochodowych;

- $\quad$ specjalistyczne badania oraz ocena właściwości fizykochemicznych i użytkowych:

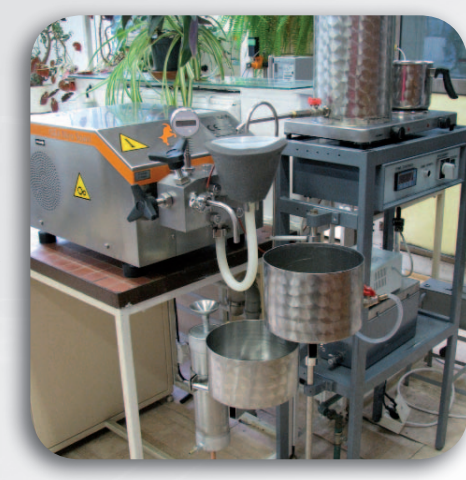

" środków smarowych, smarów plastycznych, olejów przemysłowych i silnikowych,

» wosków naftowych, wosków specjalnych oraz kompozycji i emulsji woskowych,

» asfaltów drogowych przemysłowych oraz emulsji asfaltowych, a także roztworów i mas oraz innych specyfików asfaltowych;

- opracowywanie zagadnień związanych z gospodarką olejami odpadowymi i odpadami rafineryjnymi

- $\quad$ sporządzanie ekobilansów procesów technologicznych metodą Oceny Cyklu Życia (LCA);

- $\quad$ prowadzenie sekretariatu Podkomitetu ds. Asfaltów KT 222.

Kierownik: mgr inż. Stefan Ptak

Adres: ul. Łukasiewicza 1, 31-429 Kraków

Telefon: 12 617-75-74

Faks: 12 617-75-77, 12 617-75-22

E-mail: stefan.ptak@inig.pl 